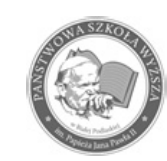

Authors' contribution/ Wkład autorów:

A. Zaplanowanie badań/

Study design

B. Zebranie danych/

Data collection

C. Analiza statystyczna/

Statistical analysis

D. Interpretacja danych/

Data interpretation

E. Przygotowanie tekstu/

Manuscript preparation

F. Opracowanie

piśmiennictwa/

Literature search

G. Pozyskanie funduszy/

Funds collection
ISSN 2083-3725

Volume 11, No. 1, 2018

\section{REVIEW OF A MONOGRAPH BY ANNA NOWAK, ENTITLED “COMPETITIVENESS OF EASTERN POLAND AGRICULTURE". SCIENTIFIC DISSERTATIONS OF THE UNIVERSITY OF LIFE SCIENCES IN LUBLIN, LUBLIN 2017, P. 200}

\author{
RECENZJA MONOGRAFII ANNY NOWAK PT. \\ „KONKURENCYJNOŚĆ ROLNICTWA POLSKI WSCHODNIEJ”. \\ ROZPRAWY NAUKOWE UNIWERSYTETU PRZYRODNICZEGO W LUBLINIE, \\ LUBLIN 2017, S. 200
}

Dionizy Niezgoda

\begin{abstract}
${ }^{1}$ Pope John Paul II State School of Higher Education in Biała Podlaska Państwowa Szkoła Wyższa im. Papieża Jana Pawła II w Białej Podlaskiej
\end{abstract}

Niezgoda D. (2018), Review of a monograph by Anna Nowak, entitled "Competitiveness of Eastern Poland agriculture". Scientific Dissertations of the University of Life Sciences in Lublin, Lublin 2017, p. 200/ Recenzja monografii Anny Nowak pt. „Konkurencyjność rolnictwa Polski Wschodniej”. Rozprawy Naukowe Uniwersytetu Przyrodniczego w Lublinie, Lublin 2017, s. 200. Economic and Regional Studies, Vol. 11, No. 1, pp. 132-136. https://doi.org/10.29316/ers-seir.2018.10

Dr hab. Anna Nowak is the author of a monograph devoted to the competitiveness of agriculture in Eastern Poland, including the following provinces: Lubelskie, Podkarpackie, Podlaskie, Świętokrzyskie and Warmian-Masurian. These regions are among the poorest in the country as well as in the whole European Union (EU). Therefore, the subject of the author's research was to search for a way to improve the competitiveness of agriculture in Eastern Poland. This area is included in peripheral regions and has not been the subject of intensive scientific research so far, which results could contribute to the development of such competition strategies that would enable strengthening the competitive advantage of agriculture, and thus the quality of life of the region's inhabitants.

The author, looking for effective solutions to this very difficult problem, read and used 467 literature references for her monograph, including $31 \%$ in English. In addition, it included legal acts, websites, source materials, e.g. by European Commission and selected local government units, numerical data of the GUS and Polish FADN annals.

From the above, it follows that author's research was very labor-intensive. However, what is more important is that these go beyond the most commonly used methodological standards. An example of this is the double-level research, i.e. at the level of regions and the level of individual farms. Thus, synchronization
Dr hab. Anna Nowak jest autorem monografii poświęconej konkurencyjności rolnictwa w Polsce Wschodniej obejmującej województwa: lubelskie, podkarpackie, podlaskie, świętokrzyskie oraz warmińsko-mazurskie. Regiony te zaliczane są do najbiedniejszych zarówno w kraju, jak i w Unii Europejskiej (UE). Stąd przedmiotem badań Autorki było poszukiwanie sposobu na poprawę konkurencyjności rolnictwa w Polsce Wschodniej. Obszar ten zaliczany jest do peryferyjnych regionów i dotychczas nie był przedmiotem intensywnych badań naukowych, których wyniki mogłyby się przyczynić do opracowania takich strategii konkurowania, które umożliwiłyby wzmocnienie przewagi konkurencyjnej rolnictwa, a przez to i jakości życia mieszkańców tego regionu.

Autorka poszukując skutecznych rozwiązań tego bardzo trudnego problemu zapoznała się i wykorzystała w monografii 467 pozycji piśmiennictwa, w tym $31 \%$ anglojęzycznego. Ponadto uwzględniła akty prawne, strony internetowe, materiały źródłowe np. Komisji Europejskiej i wybranych jednostek samorządu terytorialnego, dane liczbowe roczników GUS oraz Polskiego FADN.

Z powyższego wynika, że przeprowadzone badania były bardzo pracochłonne. Istotniejsze jest jednak to, że wykraczają one poza najczęściej stosowane standardy metodyczne. Przykładem tego jest dwupoziomowość badań tj. poziom regionów i poziom gospodarstw rolnych. Tym samym synchronizacja

Address for correspondence/ Adres korespondencyjny: prof. zw. dr hab Dionizy Niezgoda, Państwowa Szkoła Wyższa im. Papieża Jana Pawła II w Białej Podlaskiej, Wydział Nauk Ekonomicznych i Technicznych, ul. Sidorska 95/97, 21-500 Biała Podlaska, Poland; tel. +48 83 344-99-05; e-mail: d.niezgoda@onet.pl Journal indexed in/ Czasopismo indeksowane w: AgEcon Search, AGRO, BazEkon, Index Copernicus Journal Master List, ICV 2016: 92,91; Polish Ministry of Science and Higher Education 2016: 9 points / AgEcon Search, AGRO, BazEkon, Index Copernicus Journal Master List ICV 2016: 92.91; Ministerstwie Nauki i Szkolnictwa Wyższego 2016: 9 punktów. Copyright: (C) 2018 Pope John Paul II State School of Higher Education in Biała Podlaska, Dionizy Niezgoda. All articles are distributed under the terms of the Creative Commons Attribution-NonCommercial-ShareAlike 4.0 International (CC BY-NC-SA 4.0) License (http://creativecommons.org/licenses/by-nc-sa/4.0/), allowing third parties to copy and redistribute the material in any medium or format and to remix, transform, and build upon the material, provided the original work is properly cited and states its license. 
between them has de facto become the main basis for direct and indirect competitiveness research. The need and usefulness of research into the competitive position (competitiveness of the result) and the ability to compete (factor competition) were also appreciated. Such a wide substantive scope of the studied bibliography and an in-depth analysis of competitiveness confirm the author's care for a high quality of the monograph.

The main objective of this dissertation "was to assess the competitiveness of agriculture in five provinces co-creating the macro-region of Eastern Poland (...), as well as to identify the most important determinants of this competition (p. 9)". With this in mind, the author formulated the following hypotheses:

1. "The competitiveness of agriculture is a complex and multifaceted phenomenon, shaped by a number of factors, which results in the lack of unanimity in its definition and measurement.

2. Agriculture plays a significant role in the economy of Eastern Poland provinces.

3. Provinces of Eastern Poland have diversified endogenous potential of agriculture, defining the possibilities of shaping the competitive position of this sector.

4. The level of competitiveness in terms of production potential of agriculture is different from the level of competitiveness in terms of achieved results.

5. The level of competitiveness of agriculture and the level of socio-economic development of the region are interdependent phenomena.

6 . The level of competitiveness of farms in provinces of Eastern Poland is lower than the average level of competitiveness of farms in the country.

7. Human capital plays a significant role among the determinants of the competitiveness of farms (pp. 9 - 10).“

The wide substantive scope of these hypotheses was the result of the high diversity of endogenous potential of the provinces studied, the intensity of competitiveness of agriculture and the achievable competitive advantage that determines the rate of development of the studied regions. The research procedure adopted by the author was decisive for the structure of the monograph. This is confirmed by logical arrangement of chapters.

In Chapter 2, entitled "Competitiveness in Economic Theory" the attention is focused on the economic competitiveness theories, stressing a wide range of research according to levels of economic analysis. The specificity of agriculture was a necessary and important scope of competitiveness research.

In Chapter 3 defining "Determinants and measures for assessing the competitiveness of agriculture", the factors shaping the competitiveness of regions and farms were systematized. It made it possible to select the appropriate measures for agriculture competitiveness and to implement a two-level scope of research, which is based on direct and indirect competition. między nimi de facto stała się główną podstawą badań konkurencyjności bezpośredniej i pośredniej. Doceniono też potrzebę i użyteczność badań pozycji konkurencyjnej (konkurencyjność wynikowa) oraz zdolności konkurowania (konkurencja czynnikowa). Tak szeroki zakres merytoryczny przestudiowanej bibliografii oraz pogłębiona analiza konkurencyjności potwierdzają dbałość Autorki o wysoką jakość monografii.

Celem głównym tej rozprawy naukowej „była ocena konkurencyjności rolnictwa pięciu województw współtworzących makroregion Polski Wschodniej (...), a także zidentyfikowanie najważniejszych determinant tej konkurencji (s. 9)". Mając to na uwadze Autorka sformułowała następujące hipotezy:

1. „Konkurencyjność rolnictwa jest zjawiskiem złożonym i wieloaspektowym, kształtowanym przez szereg czynników, czego konsekwencją jest brak jednomyślności co do jej definiowania i pomiaru.

2. Rolnictwo odgrywa istotną rolę $\mathrm{w}$ gospodarce województw Polski Wschodniej.

3. Województwa Polski Wschodniej dysponują zróżnicowanym potencjałem endogenicznym rolnictwa, wyznaczającym możliwości kształtowania pozycji konkurencyjnej tego sektora.

4. Poziom konkurencyjności w zakresie potencjału produkcyjnego rolnictwa jest inny niż poziom konkurencyjności w zakresie osiąganych wyników.

5. Poziom konkurencyjności rolnictwa i poziom rozwoju społeczno-gospodarczego regionu są zjawiskami współzależnymi.

6. Poziom konkurencyjności gospodarstw rolnych w województwach Polski Wschodniej jest niższy niż przeciętny poziom konkurencyjności gospodarstw rolnych w kraju.

7. Wśród determinant konkurencyjności gospodarstw rolnych istotną rolę odgrywa kapitał ludzki (s. 9-10)".

Szeroki zakres merytoryczny tych hipotez był wynikiem wysokiego zróżnicowania potencjału endogenicznego badanych województw, intensywności konkurencyjności rolnictwa oraz możliwej do osiągnięcia przewagi konkurencyjnej determinującej tempo rozwoju badanych regionów. Przyjęta przez Autorkę procedura postępowania badawczego zdecydowała o strukturze monografii. Potwierdza to logiczny układ rozdziałów.

W rozdziale 2 pt. „Konkurencyjność w teorii ekonomii" skoncentrowano uwagę na ekonomiczne konkurencyjności teorii podkreślając szeroki zakres badań według poziomów analizy ekonomicznej. Koniecznym i ważnym zakresem badań konkurencyjności była specyfika rolnictwa.

W rozdziale 3 określającym „Determinanty i mierniki oceny konkurencyjności rolnictwa" dokonano systematyzacji czynników kształtujących konkurencyjność regionów oraz gospodarstw rolnych. Umożliwiło to dobór właściwych dla rolnictwa mierników jego konkurencji oraz wdrożenie dwupoziomowego zakresu badań, którego podstawą jest konkurowanie bezpośrednie i pośrednie. 
The research on factor and outcome competitiveness was carried out in 2010 - 2012 on a large group of farms being in the field of observation of the Polish FADN. The Polish FADN is a database for which information is collected according to uniform rules, and the farms form a statistically representative sample of commercial farms. Their competitiveness was assessed using the parameters of regression equations.

Chapter 4 was devoted to defining "The role of agriculture in building the competitiveness of peripheral regions". Agriculture may be an important determinant for the development of those regions, where the key role should be played by: knowledge, innovation, entrepreneurship, intellectual capital, and social capital. These factors are the main basis for initiating economic development in the peripheral regions.

In order to accelerate the pace of economic development, especially the development of the peripheral regions, it is important to increase the value added by selling raw materials processed in products with a high degree of saturation with their intellectual capital, as well as the domestic and international exports.

The structural cooperation of five regions and the development of clusters are able to reduce the negative effects of their peripherality. The model of competitiveness of regional agriculture in Eastern Poland developed by the Author is helpful in limiting the peripherality of regions.

Chapter 5 presented the issue of "The place of agriculture in the economy of the provinces of Eastern Poland". The main content of this chapter was to demonstrate the positive role of agriculture in economic development in the studied provinces of Eastern Poland. The pace of economic development varied between the regions studied. Assessing this diversity and its causes, the Author used the works of many authors. Furthermore, she selected socioeconomic indicators of the regions studied and compared them with the average results of provinces across the country.

The performed analyses of the level of specialisation highlighted the need to adapt the instruments of competition to the ecosystem properties in a given region and to the demand for specific agricultural products. The Author also justified the importance of agriculture in the development of the bioeconomy. Research showed that agriculture in Eastern Poland might contribute to the dynamic economic development of the regions studied. The results of the analysis presented in this chapter confirmed the important role of agriculture in the economy of the provinces studied, which is also in line with the research hypotheses indicated by the Author in this respect.

Chapter 6 entitled "The competitiveness of agriculture in the provinces of Eastern Poland" included considerations, which focus on multidimensionality and complexity of competitiveness. According to the Author's opinion, which I fully share, "The specificity of agriculture
Badania konkurencyjności czynnikowej i wynikowej przeprowadzono w latach 2010 - 2012 na licznej grupie gospodarstw rolnych będących w polu obserwacji Polskiego FADN. Polski FADN jest bazą danych, dla której gromadzone są informacje według jednolitych zasad, a gospodarstwa tworzą statystycznie reprezentatywną próbę towarowych gospodarstw rolnych. Oceny ich konkurencyjności dokonano przy pomocy parametrów równań regresji.

Rozdział 4 poświęcono określeniu „Roli rolnictwa w budowaniu konkurencyjności regionów peryferyjnych". Rolnictwo może być ważna determinantą rozwoju tych regionów, w których kluczową rolę powinny odgrywać: wiedza, innowacje, przedsiębiorczość, kapitał intelektualny i kapitał społeczny. Czynniki te są główną podstawą zapoczątkowania rozwoju gospodarczego w peryferyjnych regionach.

Dla przyspieszenia tempa rozwoju gospodarczego, zwłaszcza peryferyjnych regionów, istotne znaczenie ma zwiększanie wartości dodanej poprzez sprzedaż przetworzonych surowców w produkty o wysokim stopniu nasycenia ich kapitałem intelektualnym oraz eksport krajowy i międzynarodowy.

Współpraca strukturalna pięciu regionów oraz rozwój klastrów są w stanie zmniejszyć negatywne skutki ich peryferyjności. Pomocny w ograniczaniu peryferyjności regionów jest opracowany przez Autorkę model konkurencyjności regionalnej rolnictwa w Polsce Wschodniej.

W rozdziale 5 przedstawiono problematykę „Miejsca rolnictwa w gospodarce województw Polski Wschodniej”. Główną treścią tego rozdziału było wykazanie pozytywnej roli rolnictwa w rozwoju gospodarczym $\mathrm{w}$ badanych województwach Polski Wschodniej. Tempo rozwoju gospodarczego było zróżnicowane między badanymi regionami. Oceniając to zróżnicowanie i jego przyczyny Autorka wykorzystała dorobek wielu autorów. Ponadto wybrała wskaźniki społeczno-gospodarcze badanych regionów i porównała je $z$ przeciętnymi wynikami województw w całym kraju.

Wykonane analizy poziomu specjalizacji uwidoczniły potrzebę dostosowywania instrumentów konkurowania do właściwości ekosystemu w danym regionie oraz popytu na określone produkty rolnictwa. Autorka uzasadniła też znaczenie rolnictwa w rozwoju biogospodarki. Badania wykazały, że rolnictwo w Polsce Wschodniej może przyczynić się do zdynamizowania rozwoju gospodarczego badanych regionów. Wyniki analizy przedstawione w tym rozdziale potwierdziły ważną rolę rolnictwa w gospodarce badanych województw, co jest też zgodne ze wskazanymi przez Autorkę hipotezami badawczymi w tym zakresie.

Rozdział 6 pt. „Konkurencyjność rolnictwa w województwach Polski Wschodniej" zawiera rozważania koncentrujące się na wieloaspektowości oraz złożoności konkurencyjności. W opinii Autorki, którą w pełni podzielam, „Specyfika rolnictwa oraz charakter konkurencji występującej $w$ tym sektorze wskazują na zasadność uwzględniania w ocenie konkurencyjności obok czynników ekonomiczno-organizacyjnych także czynników przyrodniczych (s. 81)”. 
and the nature of competition occurring in this sector indicate the legitimacy of including, in addition to economic and organisational factors, also the natural factors in the assessment of its competitiveness (p.81)". The diversity of climatic conditions in the regions studied is an important determinant affecting the production results in agriculture. Changes in the agricultural sector are also the result of implementation of new production technologies. These and other conditions have a growing impact on the competitiveness of agriculture, which the Author rightly emphasised in this dissertation.

I share the purposefulness of applying the Malmgista productivity index by the Author to study the total productivity in the regions. This made it possible to determine the difference in productivity of agriculture in the regions studied in relation to the remaining provinces and thus to determine the competitive advantages (Tab.23). Moreover, the Author also demonstrated that there was a discrepancy between the possessed competitive potential and its productivity. The thoroughness of the research analysis made it possible to identify the reserves of the agricultural productivity growth in regions and farms. The use of many research methods by the Author confirms that she mastered the scientific workshop very well.

In the final 7th chapter, entitled "Competitiveness of farms in the provinces of Eastern Poland in the light of data from the Polish FADN", the Author assessed the competitiveness of farms in five provinces studied. The research was carried out in 2010-2012 on the basis of the most reliable numerical data of the Polish FADN. It turned out that the production results of farms are different between the regions studied. The highest average economic value was achieved by farms in the Warmian-Masurian province. In other regions, the economic value of the agricultural holdings studied was significantly lower than the national level. The lowest production potential was established in farms of the Podkarpackie and the Świętokrzyskie provinces.

The levels of average economic value achieved by farmers in holdings of different regions were the result of diversification of natural conditions, production structure, and demand. The Author demonstrated that the gross value added is the best resulting category of agricultural holdings used to assess the effectiveness of farms.

The Author has the ability to use methods appropriate to econometrics and to interpret the results of regression equations. In addition, she applied comparative analysis of other research results, which had a positive impact on the reliability of the evaluation of her results. What is also significant is the assessment of the impact of intellectual capital on the productivity of the labour factor in the farms studied.

The analysis of this dissertation demonstrates that the Author mastered the economic analysis and econometrics. I have a positive view about the selection of the research methods and the indicators. The strength of this dissertation is also the structure
Zróżnicowanie warunków klimatycznych w badanych regionach jest ważną determinantą wpływającą na wyniki produkcyjne rolnictwa. Zmiany w sektorze rolnictwa są również wynikiem wdrażania nowych technologii produkcji. Te i inne uwarunkowania mają coraz wyższy stopień wpływu na konkurencyjność rolnictwa, co słusznie podkreśliła Autorka w tej rozprawie.

Podzielam celowość zastosowania przez Autorkę indeksu produktywności Malmgista do badania produktywności całkowitej w regionach. Umożliwiło to określenie różnicy produktywności rolnictwa $w$ badanych regionach względem pozostałych województw a poprzez to przewag konkurencyjnych (Tab. 23). Ponadto Autorka wykazała również, że występuje rozbieżność między posiadanym potencjałem konkurencyjnym a jego produktywnością. Wnikliwość analizy badań umożliwiła wskazanie rezerw wzrostu produktywności rolnictwa w regionach i gospodarstwach rolnych. Zastosowanie wielu metod badawczych przez Autorkę potwierdza bardzo dobre opanowanie przez Nią warsztatu naukowego.

W końcowym rozdziale 7 pt. „Konkurencyjność gospodarstw rolnych w województwach Polski Wschodniej w świetle danych Polskiego FADN" Autorka dokonała oceny konkurencyjności gospodarstw rolnych w pięciu badanych województwach. Badania przeprowadzono w latach 2010 - 2012 na podstawie najbardziej wiarygodnych danych liczbowych Polskiego FADN. Okazało się, że wyniki produkcyjne gospodarstw rolnych są zróżnicowane między badanymi regionami. Najwyższą średnią ekonomiczną wielkość osiągnęły gospodarstwa rolne $\mathrm{w}$ województwie warmińsko-mazurskim. $\mathrm{W}$ pozostałych regionach wielkość ekonomiczna badanych gospodarstw była znacznie niższa niż w skali kraju. Najniższy potencjał produkcyjny ustalono w gospodarstwach rolnych województwa podkarpackiego i świętokrzyskiego.

Osiagnięte przez rolników poziomy średniej wielkości ekonomicznej w gospodarstwach różnych regionów były wynikiem zróżnicowania warunków przyrodniczych, struktury produkcji oraz popytu. Autorka wykazała, że najlepszą kategorią wynikową gospodarstw rolnych służącą ocenie efektywności gospodarstw jest wartość dodana brutto.

Autorka posiada umiejętność posługiwania się metodami właściwymi ekonometrii oraz interpretacją wyników równań regresji. Ponadto posłużyła się analizą porównawczą z innymi wynikami badań co wpłynęło korzystnie na rzetelność ocen jej wyników. Nie bez znaczenia jest ocena wpływu kapitału intelektualnego na produktywność czynnika pracy w badanych gospodarstwach rolnych.

Dokonana analiza tej rozprawy naukowej wykazała, że Autorka znakomicie opanowała analizę ekonomiczną oraz ekonometrię. Dobór metod badawczych i wskaźników oceniam pozytywnie. Walorem tej rozprawy jest też struktura rozdziałów i podrozdziałów oraz dokumentowanie tez w oparciu o oceny własne jak i o obfitą bibliografię, co jest wyrazem dbałości Autorki o jakość opracowania. Dlatego wybór tematu, koncepcję badań oraz interpretację wyników oce- 
of chapters and sections, as well as the documentation of theses based on personal assessments and extensive bibliography, which reflects the Author's care for the quality of the study. That is why I find the choice of topic, the concept of research, and the interpretation of results very positive. In my opinion, it is advisable to continue the research.

To sum up, it should be stated that the proposed hypotheses were positively verified in the text of the study. niam bardzo pozytywnie. Moim zdaniem, celowe jest kontynuowanie dalszych badań.

Podsumowując należy stwierdzić, że przyjęte hipotezy zostały pozytywnie zweryfikowane w tekście opracowania. 